\title{
Securitized Referent Objects in Brazilian Defence Documents: Natural Resources, Critical Infrastructure and Energy Security
}

\author{
Henry Iure de Paiva Silva* \\ Augusto W. M. Teixeira Júnior ${ }^{* *}$
}

\begin{abstract}
How do Brazil's defence documents incorporate natural resources and critical infrastructure as political and strategic components of the national energy security framework? After presenting the contemporary international landscape on the subject, which is marked by rising powers and geopolitics, the paper explains the theory and the conceptual foundations that support the claim of a securitization movement on natural resources and critical infrastructure that relates to energy security in response to the absence of existential threats to Brazil. Following this effort, the text reflects upon and analyses how the matter has developed from 2005 to 2016 in Brazilian defence policies and in national defence strategies. By applying securitization theory to the case study, the final remarks imply the need for a reflection on the importance of incorporating the geopolitics of natural resources and critical infrastructure related to energy security in defence thinking.
\end{abstract}

Key words: natural resources; critical infrastructure; energy security; defence documents; Brazil.

\section{Introduction}

The $21^{\text {st }}$ century holds important parallels to the $20^{\text {th }}$ century. Firstly, as was the case 100 years ago, a sense of decay of the dominant power in the international system continues to be observed (Allison 2017). Secondly, the distribution of international power, defined by Waltz (2002) as polarity, not only gives space to emerging powers but also opens up the dispute for influence in different strategic regional arenas (Gurganus 2018; Ellis 2018, 2019). Finally, in a multipolar world in the making, where time and space are compressed

\footnotetext{
* Federal University of Paraíba (UFPB), João Pessoa-PB, Brazil; iurepaiva@hotmail.com. ORCID iD 00000003-3989-6206.

** Federal University of Paraíba (UFPB), João Pessoa-PB, Brazil; augustoteixeirajr@gmail.com. ORCID iD 0000-0002-2569-1755.
} 
by the effect of technology, two variables' importance remains intact, namely natural resources and critical infrastructure related to energy security.

In this scenario, the variables mentioned above are fundamental not only for economic growth and development, but also for sovereignty and national defence. Brazilian geopolitics has historically incorporated the idea of development and security as two sides of the same coin. Both objectives are perceived as a political mission of the State and a value to be defended. ${ }^{1}$ Brazilian geopolitical thinkers such as Couto e Silva and Bertha Becker (Mattos 2002) have always been sensitive regarding the issue of natural resources, including those related to energy. In Brazil, the dispersion of valued resources across the national territory creates challenges for security and military defence. Fear of 'international greed' is again present due to an international scenario marked by instability and uncertainty. This strategic landscape exerts pressure on Brazilian natural resources and reveals the country's vulnerabilities concerning its national critical infrastructure.

This work analyses how the issue of natural resources and the critical infrastructure related to energy security is addressed in the main documents on National Defence in Brazil $^{2}$ (2005-2016). We start from the hypothesis that the defence of natural resources and critical energy infrastructure constitutes a new link in the traditional connection between security and development in Brazil. This is due to a securitization movement visible in national defence documents that refer to issues such as natural resources, critical infrastructure, and energy security. Despite the fact that the defence documents do not state that there are perceived threats to national sovereignty, the issues of 'international greed' for natural resources and the vulnerabilities concerning critical infrastructure, especially in the field of energy, are nonetheless present in the military strategic imaginary, functioning as a security reference object. ${ }^{3}$

The ideas expressed above indicate that, in the 2005-2016 generation of Brazilian defence documents, one issue stood out in the public debate: the protection of national natural resources and critical infrastructure, including energy. But what role does this play in the national defence documents between 2005 and 2016? Is it possible to affirm that a securitization process of natural resources and critical infrastructure was in place? This paper starts from the hypothesis that, due to the lack of perception of traditional threats by the Brazilian State, it adopts the defence of natural resources and critical infrastructure (energy) as a security objective. By doing so, it reflects in the hypothesis of [military] strategic posture. If confirmed, this relationship would be visible in the national defence policy and official strategy documents.

The specialized literature has focused on several features of the relationship between energy and defence in Brazil. The analyses range from the theoretical/conceptual debate on energy, security, and defence (Foguel, Paiva and Medeiros 2014), to the securitization of the issue (Paiva 2015; Santos 2015), defending critical energy infrastructure (Vicente 2014; Demeterco 2011; Paiva 2016), the relationship between Brazilian natural energy resources with the defence of the South Atlantic (Acioly and Moraes 2011; Nasser and Moraes 2014; Paiva 2017), and the defence of the Amazon (Teixeira Júnior and Nobre 2012; Nobre 2015; Moreira 2017). However, scientific production in Brazil and abroad 
lacks a systematic analysis that highlights the role that natural resources and critical energy infrastructure play in national defence documents in Brazil.

To coherently develop the analysis proposed here, this text has three more sections. First, we present useful theoretical backgrounds and concepts for the documentary analysis that will follow, such as the debate on securitization and dissuasion. Secondly, based on the hypothesis of securitization, we present an analysis of how the issue of natural resources and critical infrastructure, with an emphasis on energy sources, are incorporated in the National Defence Policy $(2005,2012,2016)$ and in the National Defence Strategy $(2008$, $2012,2016)$ documents. Finally, we present the main conclusions drawn from the research and developed throughout the text and compare them with our hypothesis.

\section{The connection between defence, natural resources, and energy critical infrastructure}

The first decade of the $21^{\text {st }}$ century was an important period for both institutional evolution and defence thinking in Brazil. In a general context of a multipolar order still under construction, an international scenario prone to crises linked to pressures on scarce resources, such as oil and gas, is among the situations that have exacerbated the landscape marked by uncertainty. During that period, immersed in the world in transition, Brazilian leaders perceived the country's strategic surroundings, such as South America and the South Atlantic, as possible objects of pressure and international dispute.

In its continental and maritime expression, the Brazilian geopolitical environment is characterized by the abundance of natural resources and a certain dispersion of its critical infrastructure throughout its territory. However, this apparent comparative advantage was weakened by problems related to South American cohesion and integration, as well as by a regional military fragility in view of uncertainty. It was amidst such a scenario that innovation in defence took place, through the first review of the National Defence Policy in 2005, the publication of the National Defence Strategy and the creation of the South American Defence Council in 2008, and through the idealization of the Defence Equipment Articulation Plan in 2012.

The cornerstone of these initiatives entailed an effervescence of ideas that related to the role of Brazil in the world. For example, in 2010, the then Brazilian Minister of Defence Nelson Jobim presented a strong opposition to NATO's New Strategic Concept, whose intent was to incorporate the South Atlantic in a broader Atlantic Basin concept. Minister Celso Amorim placed a similar emphasis on the defence of the main Brazilian maritime border as he was appointed Minister of Defence. On that occasion, he stated that in addition to the indispensable defence of the population, we must protect our natural resources, starting with the wealth contained in the Amazon and in Brazilian jurisdictional waters' (Amorim 2011: 17, emphasis added by authors).

Another important actor in the year of 2010 was Marco Aurélio Garcia, the Special Advisor to the Presidency of the Republic at the time. As he analysed the Brazilian strategic 
posture in light of potential conflicts in South America during the first decade of the $21^{\text {st }}$ century, he stated that

Dissuasive strategies focused on cooperation, rather than conflict, and the creation of mechanisms capable of inhibiting extracontinental greed in relation to the region's natural reserves, especially its abundant energy sources, were emphasized (2013: 58, emphasis added by authors).

In this scenario marked by innovation in the defence policy regarding discursive and effective action, it is necessary to go beyond the investigation of history and clarify some useful concepts and theoretical backgrounds in order to propose an appropriate framework for the analysis.

This paper is part of the field of studies on energy security. Energy security is an issue that is not usually understood from just a single reflective or contextual bias (Ciută 2010; Sovacool 2011; Paiva 2015). The United Nations Development Program (UNDP 2004: 42) defined energy security as '[...] the availability of energy at all times in various forms, in sufficient quantities, and at affordable prices, without unacceptable or irreversible impact on the environment.' Daniel Yergin (2006: 70-71) highlighted the multiplicity of its conceptions as he emphasized that 'although in the developed world the usual definition of energy security is simply the availability of sufficient supplies at affordable prices, different countries interpret what the concept means for them differently'. By doing so, he implied that 'Energy-exporting countries focus on maintaining the 'security of demand' for their exports, which after all generate the overwhelming share of their government revenues.' Given this scenario, the current literature points to several factors that can be considered in the shaping of energy security, such as economic (Bohi and Tomam 1993), political (Matutinovic 2009), social (Goldthau 2014), technological (Patterson 2010), environmental (Nuttall and Manz 2008), and geopolitical (Keppler 2007), among others.

Notwithstanding the variety of components that can be incorporated, guaranteeing the protection of national natural resources and energy critical infrastructure against external threats is considered essential to a country's energy security; specifically, the risks derived from voluntary or involuntary human action (Sovacool 2011; Winzer 2012). It is precisely on these aspects that this paper intends to develop an understanding of energy security.

To this end, Brazil's documents on defence address this issue and offer a reference for understanding how the guarantee of natural energy resources and related infrastructure fits as a component of Brazilian energy security and, in turn, as a security referent for Defence policy. The analysis of such documents allows us to identify (1) which natural resources and structural assets are considered essential; (2) what threats are considered in different contexts; and (3) how the role of the Armed Forces is shaped in this scenario.

Authors such as Léfreve (2010) and Löschel et al (2010) seek to work with energy security indicators to measure it in different realities. By opting for the Copenhagen School literature, this article follows a constructivist research agenda, seeking to understand how energy security is socially constructed. 
Therefore, it is necessary to firstly define what we mean by securitization. The Copenhagen School describes securitization as

[T] he discursive process through which an intersubjective understanding is constructed within a political community to treat something as an existential threat to a valued referent object, and to enable a call for urgent and exceptional measures to deal with the threat (Buzan and Wæver 2003: 491).

According to this understanding, the 'political community' that we are dealing with consists of the Federal Executive bodies concerned with defence (especially the Ministry of Defence and the Armed Forces); the 'existential threat,' which would be 'international greed' and external intervention; and the 'valued reference object,' which could be either energy natural resources and related critical infrastructure, national sovereignty or even the country's socioeconomic development. The expression of 'urgent and exceptional measures' would be in the scope of the political understanding of defence, in the country's strategy (objectives and means), and guidelines. The reading and analysis of the defence documents that will follow allow us to qualitatively assess how energy security is normatively incorporated into defence, as if there were signs of securitization to be observed.

It is also necessary to clarify the meaning of 'energy natural resources.' Initially, it must be stressed that protecting these resources would be an essential element in the design of a country's energy security. Thus, in the national defence documents, we should be able to verify indications that natural energy resources have become a securitized reference object; that is, something 'that must be protected.'

This paper deals with strategic natural resources, mainly those concerning the energy chain, which for various reasons can be a potential source of conflicts (Humphreys 2005; Le Billon 2001). In an effort to establish an understanding of the term, Rodrigues (2015: 45-50) points out that there are multiple references and ways in which one can define a strategic natural resource, among which we can highlight, for example: from its fundamental role in the functioning of the capitalist system and in maintaining regional and world hegemony (Ramos 2011); because its use is essential, difficult to replace, and subject to some risk of interruption of supply (Klare 2012); or for being scarce and vital to economic development, which enhances geopolitical disputes due to asymmetries in their endowment (Ladies, Moreira and Vitte 2009). These references apply in a similar way to the approaches to natural energy resources that will be presented on the following pages, having been absorbed by scholars and decision makers on the matter under analysis.

In addition, it is necessary to unravel the concepts and dilemmas that involve the term 'energy critical infrastructure.' Just as the protection of energy natural resources is a fundamental component of energy national security, so is the safeguarding of this infrastructure. Similarly, we must verify the extent to which the national defence documents make these assets a securitized reference object that 'enable[s] a call for urgent and exceptional measures to deal with the threat' posed against it (Buzan and Wæver 2003: 491). 
The conflict over resources dates back throughout the history of humankind, and energy infrastructures have long been subject to deliberate attacks, registered in different circumstances and with different repercussions (Farrell et al 2004: 422-427). The energy critical infrastructure, in general, comprises the physical infrastructure necessary to produce, transform, transmit, distribute, and store energy, which is essential to guarantee national sovereignty and development (Goldthau 2014: 135). However, it has proven difficult to determine those that have the potential to effectively cause significant impacts to social well-being and the functioning of the institutions and services of a country like Brazil, which can represent significant national damage or international repercussions (Paiva 2016: 176-177). In this and in other cases, it can be understood that the definition of critical infrastructure, including energy, falls within the role of parts of society, its functioning and its resilience. It also subsidizes the provision of services, social cohesion, and the reproduction of national identity. In this way, issues concerning the protection of critical infrastructure highlight the role of things (Aradau 2012: 492), which applies equally to the case of the energy sector.

Although the elements that make up the critical infrastructure vary from country to country, there are many points in common between nations. Ordinance No. 2 of 8 February 2008 of the Institutional Security Office of the Presidency of the Republic (GSI/PR), conceptualizes critical infrastructure in Brazil in its art. 2: 'IEC [Critical Infrastructure] is considered to be installations, services and goods that, if interrupted or destroyed, will cause a serious social, economic, political, international or national security impact.' The GSI/PR Ordinance, in its art. 3, lists transport, water, telecommunications, finance, and energy among the priority areas of critical infrastructures.

Another element that needs to be made explicit regarding the relationship between energy natural resources, critical infrastructure, and defence is what we understand as a strategic posture. According to Posen (1984), strategic postures are closely related to different doctrinal preferences, such as offensive, defensive, and dissuasion/deterrence.

If, on the one hand, the official Brazilian strategic stance highlighted in the defence policy and strategy documents is dissuasion ${ }^{5}$, on the other, the country lacks a clear threat to valued referent objects for which deterrence can work. Despite the fact that the country officially does not perceive any concrete threat, it understands its security landscape in terms of risk related to 'international greed' over its natural resources in the Amazon, and more recently, in the South Atlantic Ocean. As such, it is possible that deterrence can be a coherent strategic stance if a securitization movement of energy security is implemented. If this is true, a convergence between a valued referent object (natural resources), actors (Ministry of Defence/Armed Forces), and strategic posture (dissuasive), is expected. To assess this expectation, the next section sheds light on how the 'natural resources' theme is articulated in terms of defence policy and strategy in Brazil. 


\section{Energy resources and infrastructure as a defence objective: national defence policies}

In 2005, the National Defence Policy (NDP) (Presidency of the Republic [Brazil] 2005) was published. The 2005 NDP constituted a milestone in the path of consolidation of the $\mathrm{MoD}^{6}$, in particular in its attempt to give transparency and cohesion in the understanding of defence issues between the Armed Forces and society. As previously stated, the document expresses the idea that the Brazilian perception of threats declined in the post-Cold War landscape. However, that absence of perceived existential threats to the country does not mean there are still no risks to it. The document points out that

In this century, disputes can be intensified for maritime areas, aerospace domain and sources of fresh water and energy, which are more and more scarce. Such issues can lead to interference in domestic affairs, configuring conflict frames (Presidency of the Republic [Brazil] 2005: n.p.).

This prospective reading of the 'international environment' considers the issue of natural resources as an element of attention for Defence Policy. The magnitude of Brazilian biodiversity and of other natural resources could become an 'object of international interest' (Presidency of the Republic [Brazil]2005). The turn of the century is then understood as a period that would present an adverse environment in which myriad causes, such as the scarcity of socially valued resources like fresh water and fossil fuels, could be motivators of armed conflicts. This point confirms an essential element to understanding the securitization of the energy resources and infrastructure, which refers to the identification of the possible existential threats derived from 'international greed' and external intervention.

Within a framework in which diffuse security threats prevail, this understanding has a role in the 2005 NDP's political proposition. In the document, the issue of natural resources, especially energy resources, are positioned as structuring factors for defence planning in Brazil. It lists areas that concentrate political and economic power, which are vital areas in the country in that sense. This understanding appears more clearly upon affirming the maintenance of troops in the southeast and central part of the country to guarantee the defence of the main demographic, industrial, and economic concentration, 'as well as of the infrastructure, particularly the energy generator, alongside transport and technology' (Presidency of the Republic [Brazil] 2005, emphasis added by authors).

The defence of natural resources, especially energy sources, is listed as a concern in the geographical dimension of the planning of national defence. Energy and the national political and economic centre are related to economic development, a central value in the imagination of national elites, including the military. The maintenance of a sovereign decision-making centre, of its national demographic and productive weight, as well as of the sources of inputs and the critical infrastructure for the survival and viability of the country, are factors that correlate energy and infrastructure concerns with national development. 
In terms of the securitized referent objects in the energy issue, it appears that it is framed in addition to the protection of natural energy resources and critical infrastructure related to guaranteeing the socioeconomic development of the country, which in turn, would also represent the safeguarding of national sovereignty. Therefore, there is an apparent division of categories where, on the one hand, there are referent objects that incorporate the means (resources and infrastructure), and on the other, the ends (socioeconomic development and national sovereignty).

From 2005 to 2016, the geographical priorities in defence planning unfolded as to reveal the prioritization of two fundamental areas: The Amazon and the South Atlantic. Both regions are horizons for the defence policy and are recognized for their wealth, as well as they vulnerability on land (Amazon) and maritime (South Atlantic) domains and borders.

The aforementioned maritime border is not solely the region where more than $90 \%$ of Brazil's international trade passes. On it, '[...] are the largest oil and gas reserves, essential energy sources for the country's development, in addition to the existence of fishing potential' (Presidency of the Republic [Brazil] 2005: n.p.). Its vast resources and extension propelled the Brazilian Navy to coin the expression 'Blue Amazon.' The National Defence Policy specifies which energy resources can be considered securitized referent objects, characterized as fossil, non-renewable sources of wide application, with considerable economic expression and hence subject to a great degree of 'international greed.' The Blue Amazon emerges as an important concept because it represents a defining movement of the Navy into the defence debate by defining an area of influence under which it exercises primacy in the conduct of operations. Similarly to the Brazilian Army, which is seen as the leading military branch in the effort to defend the Amazon rainforest, by adding the symbolism of the term 'Amazonia' to the maritime domain, the Navy emphasizes it as a national space to be defended (Teixeira Júnior and Nobre 2012). This perception is now projected from the territorial sea to the entire extension of the Brazilian continental platform. As shall be seen later, the emergence and incorporation of the Blue Amazon as a guiding element for defence by the naval power will influence the Navy's understanding of its role in the different versions of the National Defence Strategy. Given these considerations, another important factor for the understanding of the securitization of the energy resources is made clear, one which relates to the use of urgent and exceptional measures. This matters in terms of the 'division of labour' between the three Armed Forces, involving the Army and the Navy as priority actors in implementing measures to contain risks and possible threats against energy natural resources and related infrastructure.

The 'Green Amazon' is presented as a source of energy potential and biodiversity, both of which are likewise perceived to be subject to 'international greed.' The spectrum of risks to which the region would be exposed ranges from greed on the part of a hypothetical international coalition, which would place Brazil in a condition of asymmetry in the field of defence, to 'new threats' such as international organized crime and biopiracy. It is also worth noting that the National Defence Policy reinforces the connection between the Amazon, energy security, and defence. The document states that, 
The continuous Brazilian development brings increasing implications to the energy field with reflexes to the country's security. It falls to the Country to guarantee a diversified energy source that explores the potentialities of every available natural resource (Presidency of the Republic [Brazil] 2005: n.p.).

This articulation in the field of defence policy imposes a few strategic guidelines. According to the 2005 document, two of those stand out, the first of which is the preference for diplomatic action; the second, 'the existence of military capacity with credibility' (Presidency of the Republic [Brazil] 2005). The first acts as a form of prevention; the second, as a form deterrence. In this context, despite the fact that urgent and exceptional measures such as the use of force to safeguard energy security are foreseen, non-violent means prevail as a primary initiative in resolving potential disputes. The importance attributed to energy resources as a factor that takes part in the shaping of defence and national security is significant. From the military standpoint on international conflict, it should be noted that military operations need to mobilize an enormous amount of energy resources, and that a common consequence of war is the interruption of energy production and supply. As noted, the first Defence Policy after the creation of the Ministry of Defence connects the normative dimension of energy security, natural resources, and defence. In the official defence thinking in Brazil, in the context of an absence of manifested threats to national interests, this mental articulation appears as a referent object that faces diffuse threats and risks.

In 2012, the new version of the National Defence Policy was approved (Ministry of Defence [Brazil] 2012a). In it, the link between natural resources and defence was maintained, both in the section entitled 'The International Environment' and in additional sections that address the strategic environment and national dimension. This time, among the determinants of international disputes, among which fresh water and energy are listed, the document includes 'food' as an issue that can contribute to the emergence of foreign intervention in domestic matters. This risk is enhanced by the perception of interdependence, which 'makes it difficult to define the external and internal environments' (Ministry of Defence [Brazil] 2012a: 17).

Linked to factors such as biodiversity and natural resource reserves, once more, the issue of Brazilian terrestrial and maritime wealthy ecosystems reappears in the 2012 version of the document as an element of concern for defence policy. In addition to these previous factors, the 2012 NDP includes the issue of availability of land, as 'immense areas to be incorporated into the productive system can become an object of international interest' (Ministry of Defence [Brazil] 2012a: 18). The perception that these productive lands can be securitized referent objects raises two central issues to energy security. The first is about the long strip of land already occupied and potentially usable by crops linked to the production of bioenergy (ethanol and biodiesel). The second relates to areas that are advancing enterprises aimed at the generation of solar and wind energy, whose expansion in the country is significant. 
South America, which was among a 'strategic orientation' in 2005, became a priority for diplomatic action in terms of the Brazilian strategic environment in 2012 (Ministry of Defence [Brazil] 2012a: 21). Among the factors that gave rise to this connection is the fact that the Brazilian Amazon is shared with other South American countries. In the section named 'Brazil', the 2012 National Defence Policy reaffirms the previous understanding that the Brazilian Amazon is an object of international attention, due to its biodiversity and potential for mineral wealth. This assessment affirms that the need for 'guaranteeing the presence of the State and the vivification of the border strip are hampered, among other factors, by the low population density and long distances' (Ministry of Defence [Brazil] 2012a: 23). This political requirement to produce security expresses a long-standing understanding in the military imagination that takes shape in the Army's Presence Strategy.

The securitizing discourse of natural resources in the Brazilian Defence Policies also extends to the sea. The area of approximately 4.5 million square $\mathrm{km}$ where the Blue Amazon is located is now a subject of defence according to the NDP (Ministry of Defence [Brazil] 2012a). Once again, the possibility of economically exploiting the resources of this extensive area is reinforced by the possibilities arising from the discovery of the pre-salt layer and its oil and gas reserves. The defence of the Blue Amazon was already shown to be necessary. The reasons therefor are the fact that it constitutes a maritime frontier, and due to Brazilian international trade sea dependence and its potential for exploiting natural resources (Ministry of Defence [Brazil] 2012a: 24). Since 2007, the Blue Amazon was reinforced as a strategic idea for the Navy, just as the Brazilian Amazon is for the Army.

As in the 2005 version, the 2012 National Defence Policy presents a set of guidelines that echo both a cooperative (regional) and a dissuasive (extra-regional) emphasis. However, in the 2012 version, the issue of natural resources stands out as a link between the security referent and the defence policy. In addition to actions such as military presence, the expansion of cooperation with neighbouring countries was considered as strategic, especially when 'aiming to defend the natural wealth' of the Amazon (Ministry of Defence [Brazil] 2012a: 31). This connection between energy and defence was also expressed in guideline 7.21 , which states that

Brazil should seek the continuous interaction of the current NDP with other government policies, aiming at strengthening the infrastructure of strategic value for National Defense, particularly that of transport, energy, and communications (Ministry of Defence [Brazil] 2012a: 35).

Just as the National Defence Policy (Presidency of the Republic [Brazil] 2005), the 2012 NDP Review (Brazil 2012a) continues to establish the connection between infrastructure security and energy resources with defence, from a fundamentally military perspective.

Upon close analysis of these documents, it is possible to see that the category of energy natural resources and related infrastructure creates a division of labour between military branches. Resources linked to fossil energy, such as oil and gas, are affiliated with the Navy 
and spatially located in the maritime domain in the Blue Amazon. In turn, when the documents refer to natural resources such as biodiversity, agricultural land, or clean energy, as those derived from hydroelectric plants, these are mostly located in, and attributed to, the Army's land domain within the national territory - with an emphasis on the Brazilian Amazon, and in the south-central part of the country. The aerial dimension, on land and sea, is added to the great extent of the national territory in which the Air Force is responsible for missions and means to safeguard national defence and sovereignty. In the field of energy infrastructure and resources, the Air Force also takes action against old and new threats, which intertwine transnational organized crime with environmental problems, commonly resulting in the destruction of ecosystems and in the illegal exploitation of natural resources, among other security externalities. ${ }^{7}$

In 2016, the Ministry of Defence presented the draft of the new defence documents to the National Congress for its consideration, which occurred on 14 December 2018. The new document maintained the coherence of its predecessors regarding the link between energy natural resources and defence. In the section 'the national environment,' the National Defence Policy (Brazil 2016a) reinforced the relevance for Brazilian energy security and national development of both the Green and the Blue Amazon.

In this version of the NDP, as far as the Green Amazon is concerned, mineral resources, 'hydro energetic' potential and biodiversity are listed as elements whose security must be ensured by the development and integration of the region. Unlike the 2005 and 2012 versions, the newest proposal for a National Defence Policy clearly mentions hydroelectric energy in its securitizing discourse, placing the hydrological source as a natural resource to be considered as a reference object of national energy security. Alongside these elements, we highlight the emphasis it places on obstacles to the defence of the Amazon, among which the 'huge territorial extension, the low demographic density of the Brazilian Amazon and the mobility difficulties' were listed (Ministry of Defence [Brazil] 2016a: 7-8). Prominent in the highest-level official document on national defence, the presence strategy is noted in the political and strategic thinking related to the Amazon.

Similarly to its land counterpart, the Blue Amazon is once more highlighted in the characterization of the 'national environment', not only for its strategic relevance in the South Atlantic and for the Brazilian foreign trade, but given the fact that it incorporates high potential of living and non-living resources, such as the largest oil and gas reserves in Brazil (Ministry of Defence [Brazil] 2016a: 8). Like the Green Amazon, its oceanic expression is considered relevant to meet the future demand for energy, which is seen in the document as growing due to Brazil's development process. Again, the defence of natural resources is sustained not only because of the importance of 'environmental issues' displayed in the Defence Policy documents, but also because it is now seen as a requirement for development - a core value in the defence culture.

Another important innovation in the NDP 2016 edition is the highlighted role attributed to the renewable energies in guaranteeing that the country's growing energy demand is met, including listing sources that must be recognized as priorities. That edition states that developing the capacity to expand its energy matrix and retain the mastery 
of technologies for 'the full use of its hydroelectric, solar, wind, fossil and nuclear potential, among others' is essential for Brazil (Ministry of Defence [Brazil] 2016a: 8). In simple terms, the bill weighs in favour of renewable types of energy (hydroelectric, solar and wind) compared to non-renewables (fossil and nuclear), indicating the long-standing Brazilian vocation in this regard. This forecast is in line with the understanding of the national environment as opposed to the 2005 version, in which there was only the need to 'ensure a diversified energy matrix that exploits the potential of all available natural resources, and to the 2012 version, which did not include any reference of that nature.

As echoed by previous versions of the Policy, the 2016 edition persists in the understanding that the international environment presents energy as part of the framework of potential conflicts and wars. Again, natural resources such as energy, fresh water, and food are perceived as motivators of armed conflict or external intervention (Ministry of Defence [Brazil] 2016a: 8). Functioning as a landmark of an adverse prospective scenario for which policies and strategies must be postulated to face, the link between natural resources and defence is subordinated to two central core values: development and sovereignty. Among the means of pursuing the defence objectives, the emphasis on environmental sustainability was reinforced and inextricably embraced in the 2016 NDP, as can be seen in the following sentence:

The promotion of sustainable development, including the conservation and sustainable use of biodiversity, the use of natural resources and energy potential and the incorporation of large areas into the productive system are inseparable from national sovereignty (Ministry of Defence [Brazil] 2016a: 9).

Still on the 'international environment,' the 2016 NDP establishes an interesting connection between the question of the scarcity of natural resources and the propensity for conflict, now extended to the geographical scope of Brazil's strategic surrounding. The link between natural resources and defence is now placed in a context that goes beyond the limits of South America and the South Atlantic. In the section on the international environment, the text of the 2016 National Defence Policy highlights that, in the area which comprises the Brazilian strategic surroundings, namely South America, the South Atlantic and West Africa, there are large reserves of natural resources (Ministry of Defence [Brazil] 2016a: 10). As in a zero-sum game, the document reinforces the idea of scarcity as a motivator for conflicts in an alleged scarcity scenario.

Based on this assessment of the international, regional, and domestic scenarios, the 'Political Defence Concept' proposes to combine the defence of sovereignty and the sustainable use of natural resources, with special attention to energy sources. As previously stated, the connection between natural resources, sustainability and defence is subordinated to both development and sovereignty. Next, we will highlight the physical dimension of national sovereignty as a security reference, hereby known as Energy Critical Infrastructure. 


\section{Energy resources and infrastructure as a defence objective: national defence strategies}

The first National Defence Strategy (Ministry of Defence [Brazil] 2008b) was launched in December 2008. The Strategy, commonly known as NDS was, perhaps, the main document and innovation in the field of national defence to be launched in the past two decades. Although it is not responsible for detailing defence policy, the NDS eventually contributed with new nuances to the political objectives of national defence, as well as to the strategic directions Brazil needed to take. The 2008 NDS also envisioned the link between natural resources, related infrastructure, and defence, including the energy sector.

In general, the Strategy repeats the understanding of the Policy by pointing out the absence of perceived or declared enemies to Brazil. Since the country is in a geopolitical landscape characterized more by risk than by perceived threats themselves, the NDS opts for a dissuasive posture. According to the Strategy, in the event of a degeneration of the international security conditions, the understanding is that Brazilian Armed Forces shall be employed in the defence of the territory, in maritime, land, and air theatres. However, regarding natural resources, the defence of the 'oil platforms' (Ministry of Defence [Brazil] 2008b) is highlighted in the document. In other words, while the National Defence Policy calls attention to the incorporation of natural energy resources and related infrastructure as defence referents, the Strategy turns its defence into a hypothesis for force employment, contributing to confirm the hypothesis of this paper. We highlight below how this takes place in relation to the Brazilian Navy and Army.

The 2008 NDS points out that the Navy has three essential strategic tasks, namely the sea denial, the control of maritime areas, and power projection. Yet, it is possible to infer that the strategic priority of naval power is sea denial, and this option relates to the defence of the Blue Amazon and its natural resources and infrastructure, particularly those related to energy. This emphasis is best exemplified by missions such as defending oil platforms and ports, naval and overseas locations, and facilities. One aspect that deserves attention is that both the emphasis on sea denial and the defence of maritime facilities are linked with the nuclear-powered submarine project.

By connecting national defence to geography, the policy documents highlight the priority of both the Blue and the Green Amazon. For the naval power, the coastal area that extends from Santos (São Paulo state) to Vitória (Espírito Santo state) and the mouth of the Amazon River are the main centres of strategic attention. Three reasons explain this emphasis. The first reason is the fact that the Brazilian core maritime area is concentrated mostly along the offshore oil and gas extraction facilities, with numerous exploration stations and connections through pipelines that pass through the country's maritime zone. The second is due to the fact that these areas are the maritime border for the country's economic and demographic centre of gravity, and also an important entry and exit door for essential energy resources. The third reason is the fact that the mouth of the Amazon River is fundamental for controlling navigation within the inland Amazon and it is essential for establishing the connection between the inner rivers and the ocean. 
With regard to the Army, the Green Amazon enjoys priority in the securitizing discourse, which appears in both the defence policy documents and in the 2008 National Defence Strategy. The region, which is remarkably rich in natural resources such as energy sources, is seen as possibly threatened by a framework characterized by the increasing scarcity of primary sources. This pressure, represented in the Brazilian military culture as 'international greed', also unfolds in light of non-state security threats.

As for force development, the 2008 NSD foresaw that the Equipment and Articulation Plans submitted to the Ministry of Defence by the singular branches should include a proposal for the geographical distribution of military installations and the quantification of the necessary means for the effective attendance of the need for force employment. In this vein, the NDS considered it essential to enable the national defence system to have the means to improve surveillance and control of the territory, of the Brazilian jurisdictional waters, and of the national strategic infrastructure. Surveillance and control are considered essential elements for the shaping of the securitization of the energy issue, as established in the different editions of the National Defence Policy analysed above. It is also worth highlighting the relevant role that the NDS gives to nuclear energy, to the detriment of other energy sources that were repeatedly mentioned in the National Defence Policy, such as oil, gas, and hydroelectricity.

In this regard, in another section, the National Defence Strategy once again emphatically affirms the strategic need for Brazil to develop and dominate nuclear technology, as this could guarantee the balance and versatility of the national energy matrix, contribute to an advancement in areas such as agriculture and health, as well as enable the aforementioned nuclear powered submarine project. There is also mention of the fact that nuclear energy has encouraged Brazil to develop the potential to design and build nuclear thermoelectric plants, complementing the supply of renewable energy, especially hydroelectric energy. To this end, the NDS instigates the acceleration of the mapping, prospecting, and use of uranium deposits, also securitizing this natural energy resource and bringing it to the forefront of the debate, alongside others already listed throughout this analysis.

As it was the case with the National Defence Policy (Ministry of Defence [Brazil] 2012a), the National Defence Strategy also underwent a review in 2012. In the 2012 NDS (Ministry of Defence [Brazil] 2012b), it is clear how the energy variable gains prominence. Alongside cyber and space, the nuclear sector was included as one of Brazil's three core strategic sectors (Ministry of Defence [Brazil] 2012b: 49). Obviously, the relevance of this sector transcends its energy potential, mainly given its dual character and its condition as a sensitive technology. Nevertheless, in Strategic Guideline No. 6, the document reinforces the importance of nuclear energy. ${ }^{8}$

Another guideline, Strategic Guideline No. 21, demonstrates the connection between energy natural resources, related infrastructure, and defence, mentioning military and national mobilization in the context of speculation about the use of military power to 'safeguard the territory, the maritime trade lines, oil platforms, and national air space' (Ministry of Defence [Brazil] 2012b: 60, emphasis added by authors). The oil platforms primarily represent the infrastructure element, which can be defined as a 'Unit, inhabited 
or not, normally located in a maritime environment, used for activities related to drilling wells and the production of oil or natural gas' (Petroleum Dictionary n.d.). Yet, according to the logic defended throughout this text, the integration of these three referent objects is intimately related to the securitization of the energy issue: natural resources, related critical infrastructure, and the environment in which they are located. It is not surprising that the non-renewable sources stand out, especially those which cause strong degrading impacts on the quality of life and well-being of living beings, whether in natural or human ecosystems.

In the section entitled 'Structuring the Armed Forces', it is possible to verify the influence of the integrated perspective on natural energy resources, related infrastructure, and the environment in which they are located. As noted in the 2008 NDS version, the 2012 version states the need for 'the maintenance of troops located to ensure the defense of the main demographic, industrial and economic concentration, as well as the infrastructure, particularly the energy generator' (Ministry of Defence [Brazil] 2012b: 127, emphasis added by authors). This understanding is repeated when discussing 'Strategic Actions', particularly with regard to 'National Security', when a joint approach for the security of strategic infrastructures 'especially with regard to energy, transport, water, finance and communications' is proposed (Ministry of Defence [Brazil] 2012b: 134). Notably, the National Defence Policy mentions only energy, transport, communications, water, and finance by adding them to the National Defence Strategy. As in the 2008 NDS, the 2012 version displays five types of strategic infrastructures, incorporated as a reference object to be securitized.

Among other defence documents submitted for evaluation by the National Congress in 2016 was the draft of the new National Defence Strategy (Ministry of Defence [Brazil] 2016 b). On the issue of natural resources, it placed a greater emphasis on the nuclear sector, especially in its dual energy and technological components (Ministry of Defence [Brazil] 2016c: 31). Despite being a leaner document when compared to previous versions, the 2016 NDS brought conceptual novelties such as the National Defence Objectives (NDO), Defence Strategies (DS) and Strategic Defence Actions (SDA). Below, we list and analyse those that are most clearly linked to the issue of natural resources.

The National Defence Objective 1 (NDO-1), 'Guarantee sovereignty, heritage and territorial integrity' leads to the Defence Strategy (DS-1), the 'Strengthening of National Power, which postulates two Strategic Defence Actions (SDA). SDA-1 reinforces the importance of the development of strategic sectors, with an emphasis on nuclear energy. SDA-2 deals with the security of Strategic Structures, understood here as 'a system for capturing, treating and distributing water, generating and distributing electricity, transport systems, producing and distributing fuels, finance, communications and cybernetics' (Ministry of Defence [Brazil] 2016c: 33).

As can be seen from the documents so far analysed, further specifications are made as to which energy infrastructures should be the benchmark for securitization in the context of national defence. But in spite of that, it is worth noting that, in the twenty-four pages of the 2016 version of the National Defence Strategy, the term 'resources' appears nineteen 
times, but only in three instances a relationship with the securitization of natural resources, including energy, is identified. To be more precise, the term 'natural resource(s)' is not even once mentioned throughout the document. The three recorded occurrences are present in the sections that deal with the duty to consider Brazilian interests abroad (Ministry of Defence [Brazil] 2016c: 17-36-40). Nonetheless, in no way whatsoever this necessarily denotes that energy security is not considered in the document, either explicitly or implicitly, as previously demonstrated concerning nuclear energy.

\section{Final remarks}

This paper sought to answer the following question: How do defence documents incorporate the issue of energy natural resources and critical infrastructure? To answer the question, the research was guided by the Copenhagen School theory of securitization. In line with that theoretical affiliation, the hypothesis stated that the defence of energy natural resources and critical infrastructure was proposed as a new link between security and development, one which represents a traditional ideational construct in the Brazilian geopolitical and military imagination.

From the international framework outlined, marked by instability and uncertainty, the issue of energy natural resources stood out among the main objects of dispute and potential armed conflict in the international arena. The second section of the paper contextualized the atmosphere of the Brazilian national political thought involved in the preparation of the defence documents in the last decades. From 2005 to 2016, there was a strong securitization movement within the scope of the Federal Executive (Presidency, Ministry of Defence and Armed Forces) to advance the normative political and institutional defence framework. Within this scope, the issue of 'international greed' and the defence of energy natural resources converged with the defence of the Green Amazon (Army) and the Blue Amazon (Navy). The analysis of this context was mediated by the presentation of central concepts, widely operationalized throughout the work, such as natural resources, securitization, energy resources, critical infrastructure, and dissuasion.

As a synthesis of the findings, we observe that these express the defence of energy natural resources and their areas of concentration (Green and Blue Amazon) as valued referent objects. These new referent objects emerged as a product of a securitization process present in the defence documents, in which natural resources are discursive elements widely used to justify the existence of risks and vulnerabilities that, in order to be dealt with, require calls for urgent and exceptional measures. In the absence of existential threats or a clear referent for deterrence, the perception of 'international greed' in the context of scarcity of natural resources as potential causes of foreign intervention and armed conflicts play the role of threats amidst the defence thought. In the domestic arena, the securitization process serves as a resource to convince the 'audience' of the urgency to create defensive capabilities with a deterrent effect. As a defence initiative, just as audiences need to be convinced, actors propose the conversion of energy resources and related infrastructure into valued referent objects in the aforementioned securitization movement. Defence documents, when prepared within the scope of the Ministry of Defence, need 
to be approved by law by the National Congress and sanctioned by the President. In that sense, the process of convincing audiences takes expression in Brazil through different hearings in the Executive and Legislative branches.

As expressed by the Brazilian strategic surroundings idea, throughout the documents, the official understanding of defence policy has been expanding the geographic scope that deserves attention from Brazil. The documents echo the understandings of traditional Brazilian geopolitics. By connecting geography, politics, and history to think about politics and strategy, they list sensitive areas for national defence, among which energy critical infrastructure specifically (Blue Amazon) and energy natural resources in a broader way (Green Amazon) stand out. In this vein, the risk linked to 'international greed,' so present in the military imagination regarding the Green Amazon, transcends to the national maritime environment and is operationalized in defence policies as valued referent security objects, giving rise to political orientations, strategic propositions, and hypotheses of force employment.

Regarding the analysis of the Defence Strategies, we observe the congruence between the main geographical areas of responsibility of the Armed Forces, especially the Army and the Navy, along with key areas for national interest, namely the southeast and central part of the country, the Green Amazon, and the South Atlantic. This notion is justified not only because they border areas but also because they are sources of natural resources and the basis of critical infrastructure, such as energy (oil and gas), fresh water, agricultural land, and biodiversity.

From the data analysed so far, it is possible to assert that the hypothesis has been confirmed. Thus, we are able to affirm the existence of a discourse that securitizes natural resources and critical infrastructure in the Brazilian defence environment. Nonetheless, the securitization process has so far been partial. A more comprehensive assertion about this security movement requires further investigation in order to assess whether the securitization of natural resources and critical infrastructure of energy in defence documents is consistent with the Armed Forces' strategic projects and their preparation and employment doctrines.

\section{Notes}

1 Possibly one of the main interpreters of this idea was the general and geopolitical expert Golbery do Couto e Silva (1967).

2 The new versions of the national defense documents were delivered to the National Congress for its appreciation on 22 July 2020. As determined by Complementary Law 97/1999, Art. 9, $₫ 3$, the documents need to be approved by the National Congress. Until that occurs, the 2016 versions are still valid.

3 The formation of the geopolitical, military, economic and environmental arenas in the field of energy security can be influenced by several factors. These range from the need to pursue vital interests to national sovereignty, as well as the discovery of new sources and ways of extracting energy resources. In recent years, there has been an important change in the international scenario due to the extraction of oil and gas from oil shale, with implications to the position of the United States in the international energy order. The reduced dependence of the United States on external suppliers, a factor that affects the variation in prices of this commodity, impacts geopolitics and the international oil market (Auping et al 2016; Krane and Medlock 2018). 
4 In general, critical infrastructure includes systems, facilities and assets so vital that their destruction or incapacitation would have a debilitating impact on national security, the economy, public security, health, or well-being. Critical infrastructure can be natural, built, or virtual. The built critical infrastructure includes, for example, power distribution facilities, roads and means of transport, and communication systems. The natural critical infrastructure systems include, among others, lakes, rivers, and streams that are used for navigation, water supply, or storage. The virtual critical infrastructure includes, for example, cyber, electronic and information systems (ASCE 2009: 8).

5 According to Beaufre (1998), deterrence consists of altering the opponent's behavior by transmitting the message that his goals will be frustrated, either by retaliation or by the deterrent's ability to deny. The message is conveyed by material (means and capabilities) and psychological (credibility) codes. Ideally, deterrence takes place without the direct use of force against a contender.

6 The first national defense policy was launched in 1996 even before the creation of the Ministry of Defense (MoD) in 1999.

7 Developed by the Brazilian Air Force, Operation Ostium is an important example of how national airpower is used on this issue.

8 'The strategic sectors: space, cybernetics and nuclear' details how the nuclear sector is part of the National Defense Strategy, both as an energy resource for peaceful purposes and as a military resource, restricted to the nuclear-propulsion submarine program (Ministry of Defence [Brazil] 2012b: 95-96).

\section{References}

Acioly, L and R F de Moraes (eds). 2011. Prospectiva, Estratégias e Cenários globais: Visões de Atlântico Sul, África Lusófona, América do Sul e Amazônia. Brasília: IPEA.

Allison, G. 2017. Destined for War: Can America and China Escape Thucydides's Trap? New York: Houghton Mifflin Harcourt.

Amorim, C. 2016. A Grande Estratégia Brasileira: discursos, artigos e entrevistas da gestão no Ministério da Defesa (2011-2014). Coleção Política Externa Brasileira. Brasília: FUNAG/Editora Unesp.

Aradau, C. 2010. 'Security That Matters: Critical Infrastructure and Objects of Protection.' Security Dialogue 41 (5): 491-514.

American Society of Civil Engineers (ASCE). 2009. Guiding principles for the nation's critical infrastructure. Prepared by the ASCE Critical Infrastructure Guidance Task Committee. ASCE Press: Reston.

Auping, W L, E Pruyt, S de Jong and J H Kwakkel. 2016. 'The geopolitical impact of the shale revolution: Exploring consequences on energy prices and rentier states. Energy Policy 98: 390-399.

Baldwin, D A. 1997. 'The concept of security'. Review of International Studies 23 (1): 5-26.

Beaufre, A. 1998. Introdução à Estratégia. Rio de Janeiro: Bibliex.

Bohi, D R and M A Toman. 1993. 'Energy security: externalities and policies.' Energy Policy 21 (11): 1093-1109.

Buzan, B, O Wæver and J de Wilde. 1998. Security: a new framework for analysis. London/Colorado: Lynne Rienner Publishers.

Buzan, B and O Wæver. 2003. Regions and Powers: the structure of international security. Cambridge/ New York: Cambridge University Press.

Ciută, F. 2010. 'Conceptual Notes on Energy Security: Total or Banal Security?' Security Dialogue 41 (2): 123-144. 
Couto e Silva, G do. 1967. Geopolítica do Brasil. Rio de Janeiro: José Olympio.

Demeterco, F A. 2011. 'Segurança das infraestruturas críticas.' X Ciclo de Estudos Estratégicos Escola de Comando e Estado-Maior do Exército. At https://docplayer.com.br/20860480-Seguranca-das-infraestruturas-criticas.html [Accessed on 15 August 2018].

Dicionário do Petróleo. n.d. 'Dicionário do Petróleo em Língua Portuguesa. Verbete: plataforma de petróleo/petroleum platform, offshore platform.' At http://dicionariodopetroleo.com.br/dictionary/ plataforma-de-petroleo/ [Accessed on 11 May 2020].

Ellis, R E. 2018. The Future of Latin America and the Caribbean in the Context of the Rise of China. Washington, DC: Center for Strategic and International Studies.

. 2019. 'The U.S. Military in Support of Strategic Objectives in Latin America and the Caribbean.' PRISM - The Journal of Complex Operations 8 (1): n.p.

Farrell, A E, H Zerriffi and H Dowlatabadi. 2004. 'Energy infrastructure and security.' Annual Review of Environment and Resources (29): 421-469.

Foguel, J, A L Paiva and S Medeiros. 2015. 'Por uma análise das relações entre a Segurança Energética e a Defesa.' Revista da Escola de Guerra Naval 20 (2): 401-434.

Garcia, M A. 2010. 'Recursos naturais e conflito na América do Sul.' In N Jobim, S W Etchegoyen and J P Alsina Jr. (eds), Segurança Internacional: Perspectivas brasileiras. Rio de Janeiro: FGV Editora, pp. 293-304.

2013. 'Dez anos de Política Externa.' In E Sader (ed), 10 anos de governos pós-neoliberais no Brasil: Lula e Dilma. São Paulo: Boitempo; Rio de Janeiro: FLACSO Brasil, pp. 53-68.

Goldthau, A. 2014. 'Rethinking the governance of energy infrastructure: Scale, decentralization and polycentrism.' Energy Research \& Social Science (1): 134-140.

Gurganus, J. 2018. 'Russia: Playing a Geopolitical Game in Latin America.' Carnegie Endownent for Peace.

Humphreys, M. 2005. 'Natural resources, conflict, and conflict resolution: Uncovering the mechanisms.' Journal of conflict resolution 49 (4): 508-537.

Jobim, N. 2010. Palestra do ministro da Defesa do Brasil, Nelson A. Jobim no Encerramento da Conferência Internacional - 'O Futuro da Comunidade Transatlântica.' Lisboa, Instituto de Defesa Nacional. At http://www.defesanet.com.br/defesa/noticia/3381/JOBIM---O-Futuro-daComunidade-Transatlantica/ [Accessed on 19 May 2020].

Keppler, J H. 2007. International Relations and Security of Energy Supply: Risks to Continuity and Geopolitical Risks. A study requested by the European Parliament's Committee on Foreign Affairs. Brussels: European Parliament. At https://www.ifri.org/en/publications/publications-ifri/ouvrages-ifri/international-relations-and-security-energy-supply [Accessed on 19 May 2020].

Klare, M. 2012. The race for what's left: The global scramble for the world's last resources. New York: Picador. Books.

2009. Rising powers, shrinking planet: The new geopolitics of energy. New York: Metropolitan

Krane, J and K B Medlock III. 2018. 'Geopolitical dimensions of US oil security.' Energy Policy 114: 558-565.

Le Billon, P. 2001. 'The political ecology of war: natural resources and armed conflicts.' Political Geography 20 (5): 561-584. 
Lefèvre, N. 2010. 'Measuring the energy security implications of fossil fuel resource concentration.' Energy Policy 38 (4): 1635-1644.

Löschel, A, U Moslener and D T G Rübbelke. 2010. 'Indicators of energy security in industrialised countries.' Energy Policy 38 (4): 1665-1671.

Mattos, C de M. 2002. Geopolítica e Modernidade: a geopolítica brasileira. Rio de Janeiro: Biblioteca do Exército Editora.

Matutinovic, I. 2009. 'Oil and the political economy of energy' Energy Policy 37 (11): 4251-4425.

Ministry of Defence [Brazil]. 2008. Estratégia Nacional de Defesa. Brasília, DF. .2012a. Política Nacional de Defesa. Brasília, DF. 2012b. Estratégia Nacional de Defesa. Brasília, DF. 2016a. Política Nacional de Defesa. Brasília, DF. 2016b. Estratégia Nacional de Defesa. Brasília, DF.

Moreira, A S. 2017. 'As ameaças sobre a Amazônia Verde e Amazônia Azul: Uma relação possível?' Revista da Escola de Guerra Naval 23 (1): 239-274.

Nasser, R M and R F de Moraes (eds). 2014. O Brasil e a segurança no seu entorno estratégico: América do Sul e Atlântico Sul. Brasília: Ipea.

Nobre, F. 2015. 'Recursos naturais na região amazônica: cooperação ou conflito?' Politica Hoje 23 (1): 65-92.

Nuttall, W J and D L Manz. 2008. 'A new energy security paradigm for the twenty first century' Technological Forecasting and Social Change 75 (8): 1247-1259.

Paiva, I. 2017. 'Defesa do Atlântico Sul e segurança energética no Brasil.' Revista da Escola de Guerra Naval 23 (1): 157-190.

. 2016. 'National defense policy and the protection of the critical energy infrastructure in

Brazil.' Austral Brazilian Journal of Strategy \& International Relations 5 (10): 182-208.

2015. As dimensões militares, ambientais e econômicas da segurança energética: análise a partir dos desafios e oportunidades do Brasil no contexto internacional. Ph.D. thesis. Universidade Estadual de Campinas, Brazil.

Patterson, W. 2010. 'Managing Energy: Rethinking the Fundamentals.' Chatham House Working Paper.

Posen, B R. 1984. The Sources of Military Doctrine: France, Britain and Germany Between the World Wars. Ithaca: Cornell University Press.

Presidency of the Republic [Brazil]. 1996. Política de Defesa Nacional. Brasília, DF. 2005. Política de Defesa Nacional. Brasília: DF.

Ramos, G C D. 2011. 'La gran minería en América Latina, impactos e implicaciones.' Acta Sociológica 54 (1): $17-47$.

Rodrigues, B S. 2015. Geopolítica, recursos naturais, América do Sul. MA dissertation, Universidade Federal do Rio de Janeiro, Brazil.

Santos, L W dos. 2015. 'O Processo de Securitização da Energia e suas Condições Facilitadoras' Revista Eletrônica de Direito Internacional 15 (1): 1-35. 
Senhoras, E M, F Moreira and C de C S Vitte. 2009. 'A agenda exploratória de recursos naturais na América do Sul: da empiria à teorização geoestratégica de assimetrias nas relações internacionais.' $12^{\circ}$ Encuentro de Geógrafos de América Latina - caminando en una América Latina en transformación. Montevideo, Uruguai 7-9 May 2009.

Sovacool, B K. 2011. 'Introduction: Defining, measuring, and exploring energy security.' In B K Sovacool (ed), The Routledge Handbook of Energy Security. London and New York: Routledge, pp. $1-42$.

Teixeira Jr, A W M and F R F Nobre. 2012. 'Mudanças no significado estratégico da Amazônia nas políticas e na estratégia nacional de defesa.' Revista de Geopolitica 3 (2): 113-123.

United Nations Development Program (UNDP). 2004. World Energy Assessment: Overview 2004 Update. New York: UNDP.

Vicente, E P. 2014. 'A proteção de infraestruturas críticas em energia, X Ciclo de Estudos Estratégicos Escola de Comando e Estado-Maior do Exército.' At https://docplayer.com.br/19902762-A-protecao-de-infraestruturas-criticas-em-energia.html [Accessed on 15 August 2018].

Waltz, K N. 2002. Teoria das Relações Internacionais. Lisboa: Gradiva.

Winzer, C. 2012. 'Conceptualizing energy security'. Energy Policy 46: 36-48.

Yergin, D. 2006. 'Ensuring Energy Security'. Foreign Affairs 85 (2): 69-82.

\section{About the authors}

Henry Iure de Paiva Silva obtained a Ph.D. in Political Science at the University of Campinas (UNICAMP). He is a Political Science and International Relations Professor at the Federal University of Paraíba (DRI/PPGCPRI/UFPB) and a leader of the Energy Security Studies Group at the same university (GESEne/UFPB). He is Coordinator of the CHAMADA UNIVERSAL CNPq project 'Análise dos acordos internacionais firmados na área de energia durante os governos Collor e Dilma (1990-2016).' His current research topics are energy security and energy international cooperation. He recently published the paper 'The place of renewable sources in Brazil's relationship with 'RICS' in the energy area: an analysis of bilateral agenda and summit declarations (1990-2018).'

Augusto W. M. Teixeira Júnior holds a Ph.D. in Political Science (UFPE) and a Postdoc in Military Sciences at the Brazilian Army Command and General Staff College (IMMECEME). He is a Political Science and International Relations Professor at the Federal University of Paraíba (PPGCPRI/UFPB) and an Associate researcher at the National Institute of Science and Technology for Studies on the United States (INCT-INEU). He is a leader of the Strategic Studies and International Security Research Group (GEESI/ UFPB) and an Associate coordinator of the PROCAD-DEFESA project 'Mísseis e Foguetes Na Defesa Nacional: O Sistema Astros como Elemento de Transformação Militar. He is also an alumni of the William J. Perry Center for Hemispheric Defense Studies. His current research topics are conventional deterrence and anti-access and area denial (A2/AD). He recently published the paper 'China in the contemporary world order: grand strategy, military modernization, and balance of power.' 


\title{
Recursos Naturais, Infraestrutura Crítica e Segurança Energética: Objetos Referentes Securitizados em Documentos de Defesa Brasileiros?
}

\begin{abstract}
Resumo: Como os documentos de defesa do Brasil incorporam recursos naturais e infraestrutura crítica como componentes políticos e estratégicos da estrutura de segurança energética nacional? Após apresentar o panorama internacional contemporâneo, marcado por potências e geopolíticas emergentes, o artigo explica a teoria e os fundamentos conceituais que sustentam a reivindicação de um movimento de securitização de recursos naturais e infraestrutura crítica relacionada à segurança energética em resposta à ausência de ameaças existenciais ao Brasil. Seguindo esse esforço, o texto reflete e analisa como o assunto se desenvolveu de 2005 a 2016 nas políticas de defesa brasileiras e nas estratégias nacionais de defesa. Ao aplicar a teoria da securitização ao estudo de caso, as considerações finais convidam à reflexão acerca da importância de se incorporar a geopolítica dos recursos naturais e da infraestrutura crítica relacionada à segurança energética ao pensamento de defesa.

Palavras-chave: recursos naturais; infraestrutura crítica; segurança energética; documentos de defesa; Brasil.
\end{abstract}

Received on 31 May 2020, and approved for publication on 8 October 2020. 